\title{
DET1 wt Allele
}

National Cancer Institute

\section{Source}

National Cancer Institute. DET1 wt Allele. NCI Thesaurus. Code C119621.

Human DET 1 wild-type allele is located in the vicinity of $15 q 25.3$ and is approximately 35

$\mathrm{kb}$ in length. This allele, which encodes DET 1 homolog protein, is involved in the modulation of protein degradation following ubiquitination. 